\title{
EXPANSION OF THE READING SPACE BUILDING TO IMPROVE THE QUALITY OF EDUCATION FOR COMMUNITY CHILDREN BELAWAN NELAYAN
}

\author{
Riza Inanda Siregar ${ }^{1}$, Rahmi Karolina ${ }^{2}$, Muhammad Agung Putra Handana ${ }^{3}$, Syahrizal ${ }^{4}$, \\ $1,2,3,4$ Department of Civil Engineering, Faculty of Engineering \\ Universitas Sumatera Utara \\ E-mail: $\underline{\text { rizasiregar@usu.ac.id }}$
}

\begin{abstract}
The condition of the reading hut, which only has the pillars of non-structural wood which has a short wooden life, requires the community to periodically replace the rotten wood pillars. Of course this will take a lot of time and costs. Children and adults at the service location have good reading interests. They routinely visit the floating reading hut, but lately people's interest has diminished because the condition of the floating library is not feasible. The woods of the floating library building are decayed and not suitable to be occupied. Especially the foundation or pillar of the building can no longer be able to survive firmly. These things are the background of the community service activities team to choose the location to be able to apply civil engineering in making foundation or as a pillar of the floating library building of Belawan Fishermen's Village. The main thing and priority that becomes the problem in the Fishermen Village which is the service partner is the reading hut that is used by the children of the Belawan Fishermen Village whose capacity is inadequate. The reading lodge does not have a terrace that can be used by local children to play and learn. In addition, the terrace can be used to prevent rainwater from entering the main room of the reading cottage. The solution offered in this program is the expansion of the reading hut in the form of a decent terrace to be used by the children of the Belawan Fishermen Village community to learn and play. The expansion of the reading hut consists of concrete pile foundations and floor plates from wooden planks or plywood boards with zinc roofs.
\end{abstract}

Keywords: Belawan, concrete, construction, reading room, wood.

\section{INTRODUCTION}

Local people have different characteristics and patterns of life from urban communities such as gender systems, behavioral patterns in exploiting fisheries resources, and social leadership to grow due to the influence of conditions and characteristics found in their environment. Communities in fishing villages tend to form groups that are suitable for their livelihood.

As a coastal person, the trust of the local community on average is Muslim with various ethnic backgrounds. On this background, life in the community is quite good, except that in terms of health, cleanliness and sanitation are not good enough. This happened because a lot of garbage carried by the sea waves collected on the shore, and the sanitation problems had no standards. They do public bathing, washing, and toilet facilities. directly into the open sea without any further processing, of course, it will cause waste and health problems.

The development of settlements that utilize the coastline as a place of residence certainly requires different infrastructure from settlements in urban areas, among others, in 
Siregar, RI. et al. Expansion Of The Reading Space Building To Improve The Quality Of Education For...

terms of the shape of houses and roads. Local people live in homes with pillars and only have paths to connect one house to another. Some of the facilities in the fishing village include prayer rooms and reading huts for school children in fishing villages.

The condition of the reading hut, which only has the pillars of non-structural wood which has a short wooden life, requires the community to periodically replace the rotten wood pillars. Of course this will take time and costs are not small.

Children and adults at the service location have good reading interests. They routinely visit the floating reading hut, but lately people's interest has diminished because the condition of the floating library is not feasible. The woods of the floating library building are decayed and not suitable to be occupied. Especially the foundation or pillar of the building can no longer be able to survive firmly. These things are the background of the community service activities team to choose the location to be able to apply civil engineering in making foundation or as a pillar of the floating library building of Belawan Fishermen's Village.

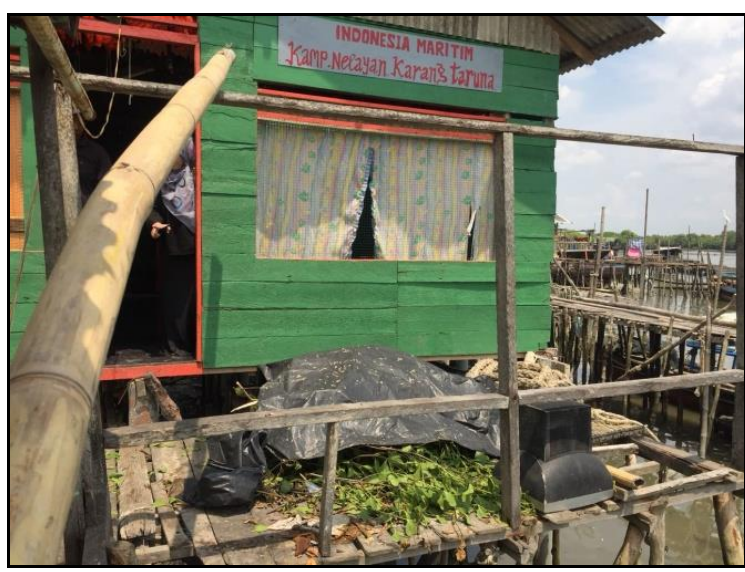

Figure 1. The front view of the reading cottage of the Belawan Fisheries Village will be expanded.
The picture above is a reading room for children in Fisherman Village. the condition that is utilized by the local community to reading book, and regular meeting in this community.

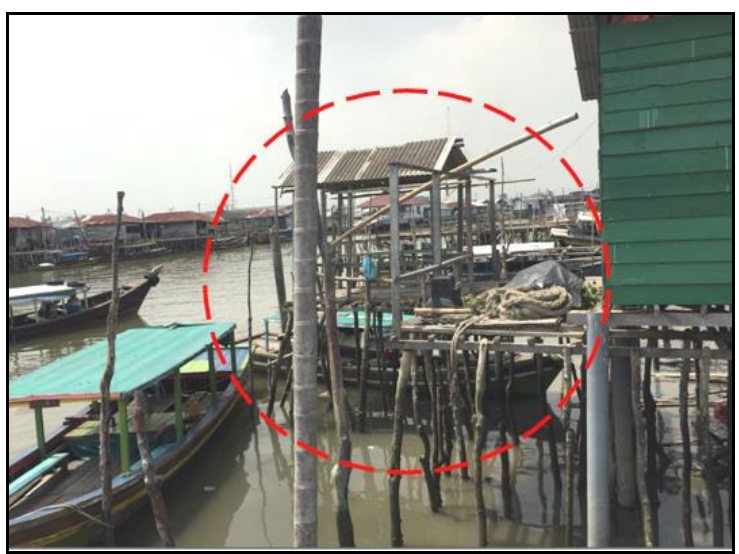

Figure 2. Conditions for the cottage to read the Belawan Fisheries Village which will be expanded

The main thing and priority that becomes the problem in the Fishermen Village which is the service partner is the reading hut that is used by the children of the Belawan Fishermen Village whose capacity is inadequate. The reading lodge does not have a terrace that can be used by local children to play and learn. In addition, the terrace can be used to prevent rainwater from entering the main room of the reading cottage.

The lack of infrastructure to read book and meet people and infrastructure used by local community to meet will certainly make it difficult for the local community to prosper in economic and education issues.

Foundations of building structure that are only made of pieces of wood from small trees and not suitable to be used as road foundations. Everyday people have to go through roads like 
Siregar, RI. et al. Expansion Of The Reading Space Building To Improve The Quality Of Education For...

this, of course there are risks that arise as the road becomes damaged if a heavy load is passed.

The floating reading lodge is actively used by the children of Belawan Fisheries Village to add insight by reading, learning and playing. Due to the frequent occurrence of rain that hit the Belawan Fisheries Village, it was feared that the main room of the reading cottage was exposed to rain, therefore it was necessary to expand the front porch of the reading cottage.

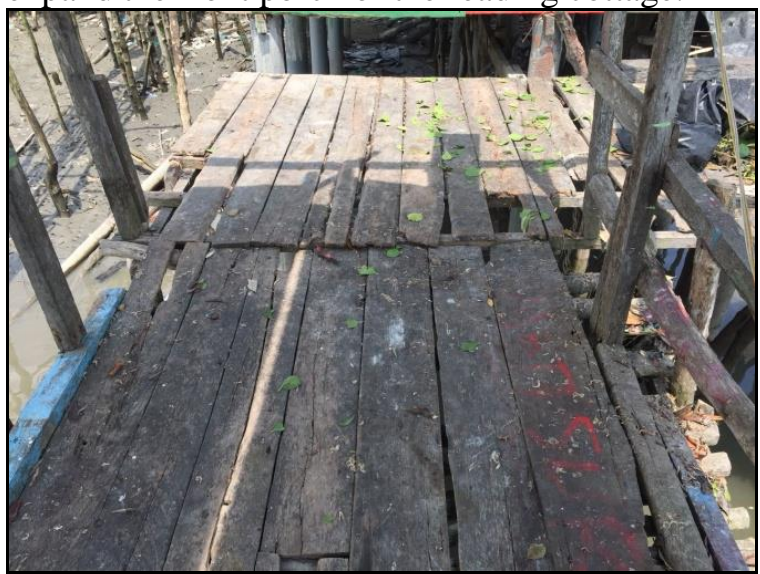

Figure 3. The conditions for reading huts that need to be expanded

The picture above which is given a red circle is an area that will be expanded in the form of a reading cottage in the form of a terrace for the children of the community of Bealwan Fishermen Village playing and learning.

Based on the problems faced by the cooperation partners that have been agreed upon, the Community Service Program was given a solution in the form of an expansion of the reading hut in the form of a terrace that was used by the children of the Belawan Fishermen Village in the fishing environment I and II. The reading cottage initially uses nonstructural wood and is already rotten and cannot be used again.

The solution offered in this program is the expansion of the reading hut in the form of a decent terrace to be used by the children of the
Belawan Fishermen Village community to learn and play. The expansion of the reading hut consists of concrete pile foundations and floor plates from wooden planks or plywood boards with zinc roofs.

\section{MATERIAL AND METHODS}

Location of study of expansion of the reading space building to improve the quality of education for community children, Fisherman Village, Belawan.

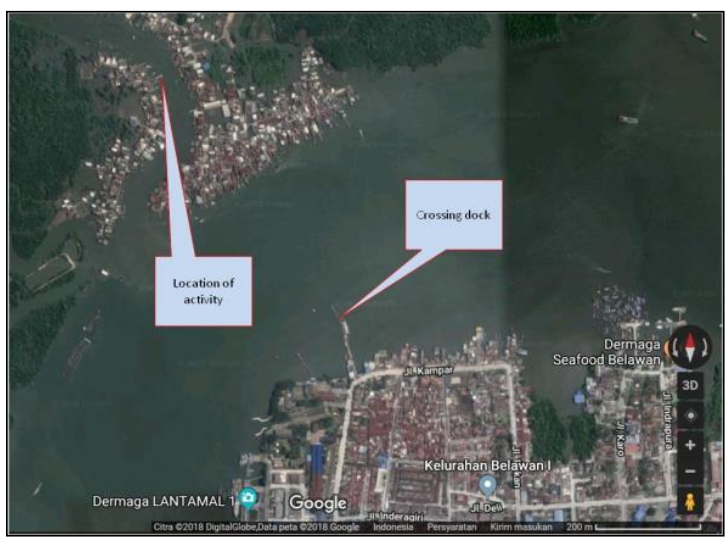

Figure 4. Location of study

In the construction of concrete roads in Belawan Fisherman Village, before carrying out concrete road works there are several stages of analysis to determine the dimensions of the concrete road to be made. Stages of concrete road implementation activities from holding the analysis until the work in the field are as follows: 1) Literature study, the purpose is to determine the method, the correct way of working and in accordance with the problems in the partner location; 2) Phase of analysis, at this stage what is done is to design the dimensions of the road; 3) Preparation of tools and materials, the purpose is to prepare the equipment and materials needed in the road construction of concrete. Tools and materials are conditioned according to the available study location; 4) Making the foundation or supporting pillar of the building, the initial 
Siregar, RI. et al. Expansion Of The Reading Space Building To Improve The Quality Of Education For...

stages of construction after the preparation of tools and materials (material) is to build a pile foundation that is adjusted to the study location. The foundation used is only pipe foundation; 5) Installation of formwork, installation of formwork / mall as concrete foundation mold to be made; 6) Casting the foundation, after being installed formwork then casting.

One thing that is unique about this concrete fondations work is the storage of materials placed under the houses of residents, especially the sand and gravel. The material is positioned in the water just below the people's house.

The concrete fondations is a rigid pavement which is a type of road pavement that uses concrete as the main material for the pavement. In the seafront building, pile foundation is used for the concrete road. In sand soil, the pile foundation is intended to compact the sand so that the capacity of the soil can increase and be able to support the foundation of the building whose surface is easily eroded by water.

The concept of the pile foundation on the concrete on the seafront is the same as the concept of the pier pile foundation which is a building with reinforced concrete structures that are located rather protruding into the water. The dead load received by the foundation on the dock structure is smaller compared to other loads that work such as wind loads and wave loads. The wind load and wave load have a tendency to move horizontally.

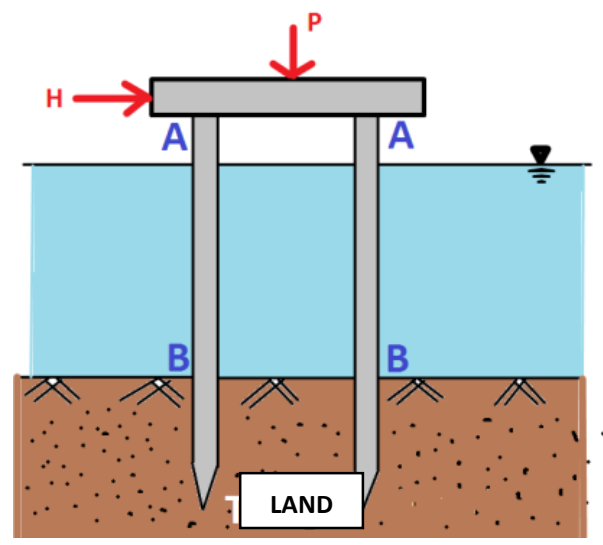

Figure 5. The concept of concrete pile foundation that will be applied to the path of Belawan Fisherman Village

Corrosion on concrete can be detrimental to us as users of the building structure, in addition to shortening the usage, the maintenance costs or repairs are often greater than the value of the building. The following is a recommendation to get a long-lasting concrete structure in the marine environment: 1) The use of basic concrete materials (such as aggregates) and good quality concrete using second type cement; 2) Selection of corrosionresistant material with an existing environment, preventing contact between iron and the environment, such as painting or coating with non-corroded material, besides that the type and quality of concrete greatly affect the corrosion resistance in concrete; 3 ) Conveying a concrete sheath with a thickness of the same as appropriate with the environmental conditions.

The stages of making concrete fondations can be explained through the following procedures tailored to the field work, namely: 1) Prepare the materials needed for the work in the field according to the planned concrete road; 2) Preparation of land by installing bowplank to determine the points of the foundation pole; 3 ) Pair the pile (pvc pipe as a casing) at the specified points; 4) Put reinforcement on the pile; 5) Prepare concrete mixture materials; 6) Site concrete mixes using molen machines; 7) Perform casting for all of the pile; 8) Install the mall / mold using plywood on the sides of the floor plate to be concrete; 9) Assembling and installing iron / reinforcement for concrete road floor plates; 10) Make a pile reinforcement connection with floor plate reinforcement; 11) Re-prepare concrete mix materials; 12) Site mix concrete using molen machines; 13) Do casting for all the concrete road floor plates; 14) Wait up to 14 days after casting is done; 15) Then open the mall / concrete mold; 16) Finish and the road is ready for use. 
Siregar, RI. et al. Expansion Of The Reading Space Building To Improve The Quality Of Education For...

The following is a picture of the initial design for the concrete road that was applied at the location of the community service activities in Belawan Fisherman Village. The picture below is the initial condition when the concrete road construction has not been made at that location.

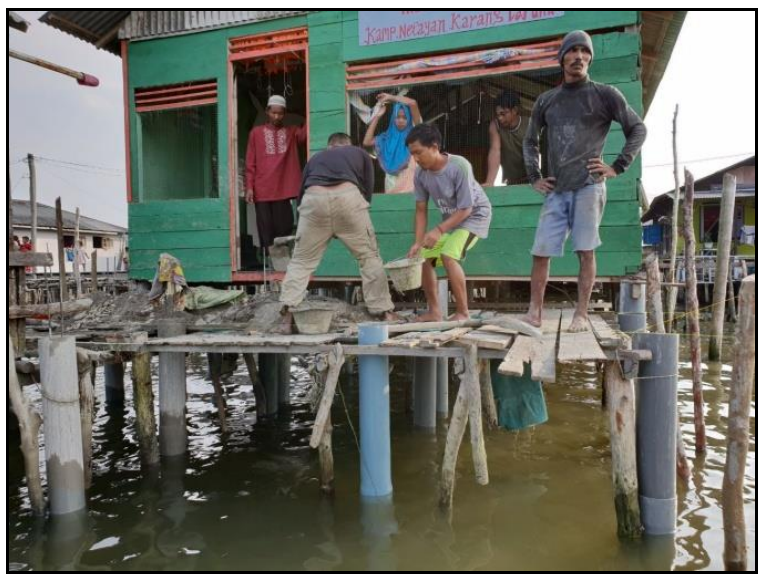

Figure 6. The conditions for the expansion of the lodge read the location of community service in the Belawan Fishermen's village.

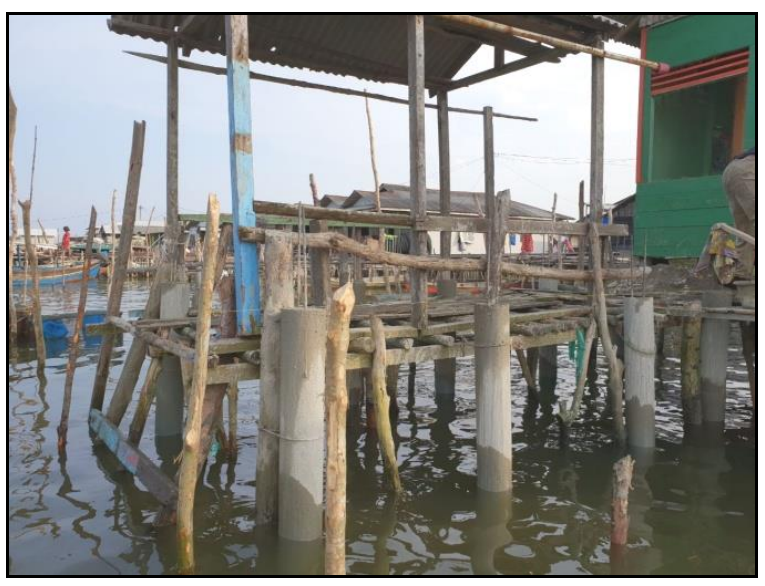

Figure 7. The condition of the expansion of the reading hut that has been cast
The activity of making concrete pile foundations using concrete material as the main material used. The concrete used consists of the following materials: 1) Portland Cement, is an important bonding material and is widely used in development; 2) Sand (fine aggregate), sand used in the manufacture of lightweight concrete is sand that passes the sieve according to ASTM E 11-70 standards whose diameter is smaller than $5 \mathrm{~mm}$; 3) Gravel (coarse aggregate) is a small rock, usually granite that is broken. The size of the gravel that is always used is between $2 \mathrm{~mm}$ and $75 \mathrm{~mm}$; 4) Water, is one of the ingredients needed to mix concrete to trigger the chemical process of cement, wet the aggregate and provide ease of work; 5) PVC pipes, used for concrete molding on concrete road piles. Polyvinyl chloride (PVC) is a pipe made of plastic and some other vinyl combinations; 6) Concrete reinforcement iron, used is $10 \mathrm{~mm}$ in size; 7) Molen machine, Molen's function is to make a stir, both for pair and plastering purposes, sand and cement are mixed evenly according to certain mixtures which will produce a concrete mixture. The molen machine consists of a stirring tube, motor, molen wheel, frame, tube inverting wheel, and lock.

\section{RESULTS AND DISCUSSION}

All stages are worked out at the service location by the dedication team and students who are included in the activity. In addition activities are assisted by the local community for the process of carrying out the construction of concrete fondations.

The series of activities lasted for several weeks which were done by the craftsmen and supervised by the team and the local community. Collaboration with fellow team members and the community helps to complete the project quickly so that the community can enjoy it. The following is documentation of the work in the field. 


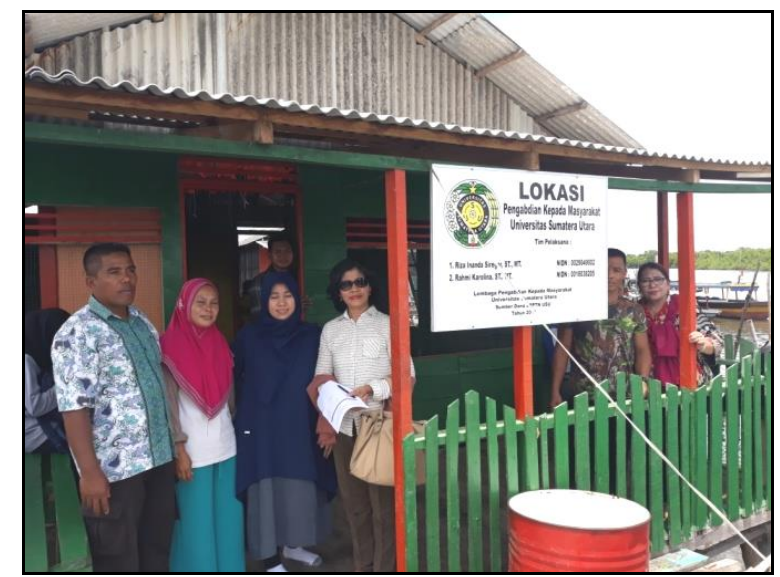

Figure 8. Team leader with partners and reviewers on monitoring and evaluation activities at the location of the activity

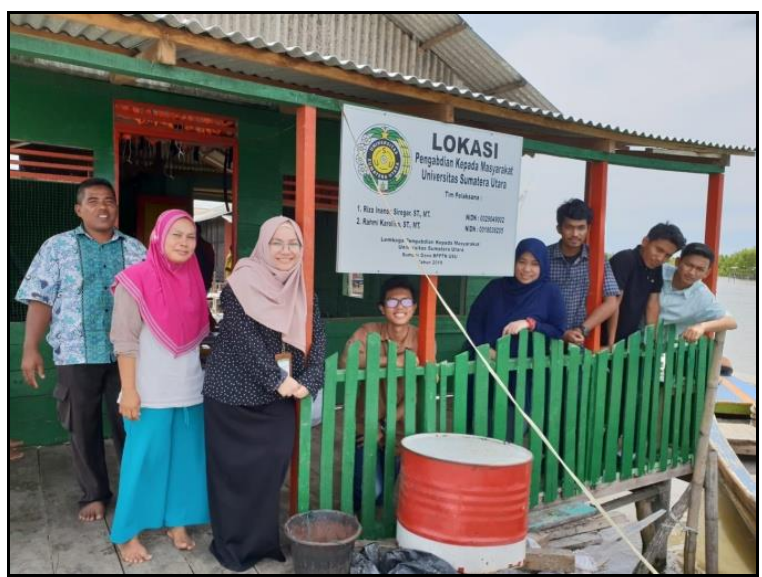

Figure 8. Team leader and team members at the location of the service activities

\section{CONCLUSIONS}

The conclusions of the Community Service Program activities include: 1) The expansion of the reading lodge to support the learning activities of the children of the Belawan fishing village community is $5 \mathrm{~m}^{2}$.2) The road foundation built has a diameter of $20 \mathrm{~cm}$ cast concrete pvc pipe. 3) The floor plate of the reading hut with black plywood boards, along with a zinc roof. 4) The Community Service Program activities carried out by the service team can be used directly by the community of Fishermen's Village, Belawan, to act as fishermen. 5) These activities can facilitate the achievement of the level of increase in the economic community.

Suggestions given for this activity include: 1) The service team hopes that in the future the expansion of reading huts for the benefit of children's learning activities can be longer and wider in size. 2) The Community Service Team expects maximum benefits for the people of Belawan Fisheries Village to improve the quality of learning for the children of the Belawan fishing village. 4) The service team also hopes to be able to reduce the problems of inadequate facilities and infrastructure in the area.

\section{ACKNOWLEDGEMENT}

A big thank to the Community Service Agency (LPM), Universitas Sumatera Utara, for the funding this community service activity which was sourced from BPPTN 2018 funds, Universitas Sumatera Utara.

\section{REFERENCES}

Abdullah Yudith, 2008, Pengaruh Zat Aditif pada Pembuatan Bata Beton Ringan, FT UI, Jakarta.

ASTM, 1997. ASTM Annual Book of ASTM Standards Section 4 Volume 04.02. ASTM 100 West Conshohocken, PA.

ASTM C 567 , Unit Weight of Structural Lightweight Concrete, American Standard for Testing Materials.

ASTM C 796 - 87 a,Table 1, Foaming Agents for Usse in Producing Cellular Concrete 
Siregar, RI. et al. Expansion Of The Reading Space Building To Improve The Quality Of Education For...

Using Preformed Foam, American Standard for Testing Materials.

ASTM C 869-91, Standard specification for foaming agents used in making preformed foam for cellular concrete, American Standard for Testing Materials.

Lukito Prasetyo, 2010, Maksimasi Kuat Tekan Beton, Malang.

Mandala Siliwangi, et al, 2014. Perancangan pondasi tiang pancang dermaga packing plant Banjarmasin-Kalimantan Selatan, Jurnal Karya Teknik Sipil, Universiats Diponegoro.
Nugraha, Paul, dan Antoni, 2007. Teknologi Beton, Yogyakarta, Penerbit Andi.

Suwandi, 2012. Perencanaan pondasi tiang pancang pipa baja pada pembangunan dermaga Melak. Jurnal Teknik Sipil dan Arsitektur, Samarinda.

Tiurma Simbolon, Pascasarjana USU, 2009, Pembuatan dan Karakterisasi Bata Beton Ringan, Medan.

Tri Mulyono, 2005, Teknologi Beton, Yogyakarta, Penerbit Andi. 